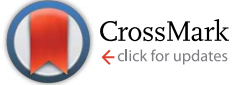

Cite this: RSC Adv., 2017, 7, 1376
Received 16th November 2016 Accepted 6th December 2016

DOI: $10.1039 / c 6 r a 26868 d$

www.rsc.org/advances

\title{
Achieving electroreduction of $\mathrm{CO}_{2}$ to $\mathrm{CH}_{3} \mathrm{OH}$ with high selectivity using a pyrite-nickel sulfide nanocomposite $\uparrow$
}

\author{
Siqi Zhao, Sijie Guo, Cheng Zhu, Jin Gao, Hao Li, Hui Huang, ${ }^{*}$ Yang Liu* \\ and Zhenhui Kang*
}

\begin{abstract}
Electrochemical reduction of carbon dioxide $\left(\mathrm{CO}_{2}\right)$ to methanol $\left(\mathrm{CH}_{3} \mathrm{OH}\right)$ catalyzed by transition metals has been proved feasible and effective in aqueous electrolytes. In this work, we introduce a $\mathrm{FeS}_{2} / \mathrm{NiS}$ nanocomposite electrocatalyst synthesized by traditional hydrothermal method, which selectively reduces $\mathrm{CO}_{2}$ to $\mathrm{CH}_{3} \mathrm{OH}$ with an unprecedented overpotential of $280 \mathrm{mV}$ and a high faradaic efficiency up to $64 \%$ at the potential of $-0.6 \mathrm{~V}$ vs. reversible hydrogen electrode (RHE). The $\mathrm{FeS}_{2} / \mathrm{NiS}$ nanocomposite electrocatalyst exhibits a stable current density of $3.1 \mathrm{~mA} \mathrm{~cm} \mathrm{~cm}^{-2}$ over a 4 hour stability test. The high selectivity towards $\mathrm{CO}_{2}$ electroreduction to $\mathrm{CH}_{3} \mathrm{OH}$ may be attributed to the special ladder structure of the $\mathrm{FeS}_{2} / \mathrm{NiS}$ nanocomposite. The active sites are located at the interface between $\mathrm{FeS}_{2}$ and NiS which can effectively suppress the side reaction hydrogen evolution reaction and facilitate the $\mathrm{CO}_{2}$ reduction reaction.
\end{abstract}

\section{Introduction}

Electrochemical reduction of $\mathrm{CO}_{2}$ to carbon-containing fuels is a feasible process which is conducive to solving the serious environmental problems caused by excess $\mathrm{CO}_{2}$ such as iceberg melting, sea level rise and coastal delta subsidence. ${ }^{\mathbf{1 - 3}}$ However, the main defects of electroreduction $\mathrm{CO}_{2}$ are the high overpotential required to drive the reaction, the low selectivity towards various products and the high cost of catalysts. ${ }^{4,5}$ The high overpotential increases the consumption of energy and makes it difficult to achieve the sustainable transformation of $\mathrm{CO}_{2}$. As for the selectivity, in addition to the major side reaction hydrogen evolution reaction (HER), the direct electroreduction of $\mathrm{CO}_{2}$ in aqueous solution is able to generate diversiform carboncontaining chemicals. ${ }^{5}$ The complex products increase the challenges towards generating target product. Transition metals are commonly proposed in $\mathrm{CO}_{2}$ reduction reaction $\left(\mathrm{CO}_{2} \mathrm{RR}\right)$ because of their vacant orbits and active d electrons. ${ }^{5}$ Among them, $\mathrm{Au},{ }^{6-9}$ $\mathrm{Ag}^{\mathbf{1 , 1 0 , 1 1}}$ and $\mathrm{Pd}^{\mathbf{1 2 , 1 3}}$ have been explored comprehensively, while the expensive price limits the substantial application of noble metals in industry. ${ }^{\mathbf{1 4}}$ Moreover, the main product from noble metals is carbon monoxide (CO), which leads to the second pollution at the cost of $\mathrm{CO}_{2}$ consumption.

Jiangsu Key Laboratory for Carbon-Based Functional Materials \& Devices, Institute of Functional Nano \& Soft Materials (FUNSOM), Soochow University, 199 Ren'ai Road, Suzhou, 215123, Jiangsu, PR China.E-mail: zhkang@suda.edu.cn; yangl@suda.edu. cn; hhuang0618@suda.edu.cn

† Electronic supplementary information (ESI) available: The supplementary figures are shown. See DOI: 10.1039/c6ra26868d
$\mathrm{CH}_{3} \mathrm{OH}$, as an ideal chemical, is an important intermediate of paint, plastics, and other common products. ${ }^{15}$ Besides, $\mathrm{CH}_{3} \mathrm{OH}$ with high energy density can be stored as liquid under ambient conditions. ${ }^{\mathbf{1 6 , 1 7}}$ The standard potential of $\mathrm{CO}_{2}$ electroreduction to $\mathrm{CH}_{3} \mathrm{OH}$ is only $0.016 \mathrm{~V}$ (vs. $\mathrm{RHE}$ ). However, the $6 \mathrm{e}^{-}$ process of $\mathrm{CO}_{2}$ reduction to form $\mathrm{CH}_{3} \mathrm{OH}$ over the full reaction is kinetically unfavorable. Significant efforts towards selectively converting $\mathrm{CO}_{2}$ into $\mathrm{CH}_{3} \mathrm{OH}$ have been made since early 1983 over semiconductor materials ( $\mathrm{p}-\mathrm{GaP}$ and $\mathrm{p}-\mathrm{GaAs}$ ) with a low current density $\left(<1 \mathrm{~mA} \mathrm{~cm}{ }^{-2}\right) \cdot{ }^{18}$ Lately, Frese et al. firstly observed Teflon-supported $\mathrm{Ru}$ electrodes could selectively reduce $\mathrm{CO}_{2}$ to $\mathrm{CH}_{3} \mathrm{OH}$ with a low faradaic efficiency (FE) of $42 \% .{ }^{19} \mathrm{Fe},{ }^{20} \mathrm{Ni},{ }^{21} \mathrm{Cu}^{22}$ and their associated complexes ${ }^{23-26}$ have been widely investigated in the yield of $\mathrm{CO}_{2} \mathrm{RR}$ as their rich distribution and low cost. Among them, copper is demonstrated as the effective catalyst for the electroreduction of $\mathrm{CO}_{2}$ to hydrocarbon and alcohols. ${ }^{27,28}$ Le et al. reported that electrodeposited cuprous oxide thin films could directly reduce $\mathrm{CO}_{2}$ to $\mathrm{CH}_{3} \mathrm{OH}$ with a rate of $43 \mu \mathrm{mol} \mathrm{cm}{ }^{-2} \mathrm{~h}^{-1}$ and low $\mathrm{FE}$ of $38 \% .^{29}$ Therefore, it is urgent to seek for a highly active, selective and effective catalyst towards electroreduction $\mathrm{CO}_{2}$ to $\mathrm{CH}_{3} \mathrm{OH}$.

Herein, we fabricated a low-cost $\mathrm{FeS}_{2} / \mathrm{NiS}$ nanocomposite by traditional hydrothermal method as an excellent electrocatalyst. $\mathrm{FeS}_{2} / \mathrm{NiS}$ nanocomposite displays incomparable operation in its low overpotential of $280 \mathrm{mV}$ and high selectivity with a $\mathrm{CH}_{3} \mathrm{OH}$ FE up to $64 \%$ at the potential of $-0.6 \mathrm{~V}$ ( $v s$. RHE). The stability test of $\mathrm{FeS}_{2} / \mathrm{NiS}$ nanocomposite was performed for 4 hours, showing a stable current density of $3.1 \mathrm{~mA} \mathrm{~cm}^{-2}$ at $-0.6 \mathrm{~V}$ ( $v s$. RHE). There is no obvious degradation of the electrocatalyst after the long-time test. The following experiments reveal the 
insight mechanism of $\mathrm{CO}_{2} \mathrm{RR}$ catalyzed by $\mathrm{FeS}_{2} / \mathrm{NiS}$ nanocomposite. As a comparison, we synthesized the single $\mathrm{FeS}_{2}$ and NiS nanocrystals and applied in $\mathrm{CO}_{2} \mathrm{RR}$, respectively. The $\mathrm{FeS}_{2}$ nanocrystal shows a negative onset potential at $-0.45 \mathrm{~V}(v s$. RHE) and a maximum current density of $4.2 \mathrm{~mA} \mathrm{~cm} \mathrm{~cm}^{-2}$ at $-0.68 \mathrm{~V}$ ( $v s$. RHE). The NiS nanocrystal shows a more negative onset potential at $-0.5 \mathrm{~V}(v s$. RHE) and extremely low current density of $1.0 \mathrm{~mA} \mathrm{~cm}^{-2}$ at $-0.68 \mathrm{~V}$ (vs. RHE). Therefore, it can speculate that the active sites of the catalyst towards the process locate at the interface of $\mathrm{FeS}_{2}$ and NiS. Besides, the $\mathrm{FeS}_{2} / \mathrm{NiS}$ nanocomposite with an average diameter of $14 \mathrm{~nm}$ greatly increases the specific surface areas and the number of active sites.

\section{Experiments}

\section{Materials}

Ferric oxide $\left(\mathrm{Fe}_{2} \mathrm{O}_{3}, 99 \%\right)$, nickel nitrate $\left(\mathrm{Ni}(\mathrm{Ac})_{2}, 99 \%\right)$, sulfur powder (99\%), 1-octanol (99\%), 1-octylamine (99\%), ethanol (99.5\%), $\mathrm{KHCO}_{3}(99.7 \%)$ and Nafion perfluorinated resin solution (5 wt\%) were purchased from Sigma-Aldrich and Adamasbeta; Nafion ${ }^{\circledR} 212$ membrane was purchased from Dupont. Deionized water (purified by a Milli-Q system) was used to prepare all solutions and to rinse samples and glassware.

\section{Instruments}

The crystal structure of the catalyst was measured by X-ray diffraction (XRD) using an X'Pert-ProMPD (Holand) D/max$\gamma \mathrm{AX}$-ray diffractometer with $\mathrm{Cu} \mathrm{K} \alpha$ radiation $(\lambda=0.154178 \mathrm{~nm})$. The high-resolution transmission electron microscopy (HRTEM) and scanning transmission electron microscopy (STEM) images were obtained using a FEI/Philips Tecnai G2 F20 TWIN transmission electron microscope. The Raman spectra were acquired with an HR 800 Raman spectroscope (J Y, France) equipped with a synapse CCD detector and a confocal Olympus microscope. X-ray photoelectron spectroscopy (XPS) was measured using a KRATOS Axis ultra-DLD X-ray photoelectron spectrometer with a monochromatised $\mathrm{Mg} \mathrm{K} \alpha \mathrm{X}$-ray source ( $h \nu$ $=1283.3 \mathrm{eV}$ ). Scanning electron microscopy (SEM) images and energy dispersive X-ray (EDX) spectroscopy were performed by Carl Zeiss Supra 55 scanning electron microscope with an acceleration voltage of $20 \mathrm{kV}$. The electro-catalysis activities were measured by a Model CHI 660C workstation (CH Instruments, Chenhua, China).

\section{Synthesis of catalyst}

$\mathrm{FeS}_{2} / \mathrm{NiS}$ nanocomposite. In a typical hydrothermal method, ${ }^{30} \mathrm{Fe}_{2} \mathrm{O}_{3}$ and $\mathrm{Ni}(\mathrm{Ac})_{2}$ were introduced as iron and nickel sources, respectively. The ratio of nickel to iron is $1: 1 . \mathrm{Fe}_{2} \mathrm{O}_{3}$ (2.5 mmol), $\mathrm{Ni}(\mathrm{Ac})_{2}(2.5 \mathrm{mmol})$ and sulphur $(50 \mathrm{mmol})$ were dissolved in $30.0 \mathrm{ml}$ 1-octylamine and $30.0 \mathrm{ml}$ 1-octanol at room temperature. Then, the mixture was transferred into a $150 \mathrm{ml}$ stainless steel autoclave and heated to $260{ }^{\circ} \mathrm{C}$ for 3 hours under nitrogen atmosphere. When cooled to room temperature, the black precipitate was collected by centrifugation and thoroughly washed with ethanol for several times.
$\mathrm{FeS}_{2}$ and NiS nanocrystals. The preparation of $\mathrm{FeS}_{2}$ nanocrystal comes from the same hydrothermal method as $\mathrm{FeS}_{2} / \mathrm{NiS}$ nanocomposite. $0.8 \mathrm{~g} \mathrm{Fe} \mathrm{O}_{3}(5 \mathrm{mmol})$ and $1.6 \mathrm{~g}$ sulfur powder (50 mmol) were dissolved in $30.0 \mathrm{ml}$ 1-octylamine and $30.0 \mathrm{ml} 1$ octanol at room temperature. Then, the mixture was transfer into a $150 \mathrm{ml}$ stainless steel autoclave. The autoclave was sealed and heated to $260{ }^{\circ} \mathrm{C}$ for 3 hours under nitrogen atmosphere. The NiS nanocrystal was synthesized with the same hydrothermal method while changed the ratio of $\mathrm{Ni}(\mathrm{Ac})_{2}$ and sulfur powder to $1: 1.5$.

\section{Electrochemical measurements}

The electrocatalytic activity measurements were performed in a standard three-electrode system. Saturated calomel electrode (SCE) was acted as the reference electrode with a standard electrode potential of $0.242 \mathrm{~V}$ ( $v s$. RHE) and platinum wire was acted as the counter electrode. The working electrode was the catalyst modified glassy carbon disk electrode (GCE, $3.0 \mathrm{~mm}$ diameter $\mathrm{CH}$ Instruments) and $0.5 \mathrm{M} \mathrm{KHCO}_{3}$ solution saturated with $\mathrm{CO}_{2}$ was used as electrolyte. The cyclic voltammetry and linear sweep voltammetry were performed at a range from 0.7 to $-0.7 \mathrm{~V}$ (vs. RHE) by a Model CHI 660C workstation under ambient condition. All the potentials reported here were versus $\mathrm{Hg} / \mathrm{HgCl}_{2}$ and were converted to the RHE scale using the Nernst equation:

$$
E_{\mathrm{RHE}}=E_{\mathrm{Hg} / \mathrm{HgCl}_{2}}+E_{\mathrm{Hg} / \mathrm{HgCl}_{2}}^{\theta}+0.0591 \times \mathrm{pH}_{\text {electrolyte }}
$$

$E_{\mathrm{RHE}}$ is the converted potential versus RHE. $E_{\mathrm{Hg} / \mathrm{HgCl}_{2}}$ is the external potential measured against the $\mathrm{Hg} / \mathrm{HgCl}_{2}$ reference electrode. $E_{\mathrm{Hg} / \mathrm{HgCl}_{2}}^{\theta}$ is the standard potential of $\mathrm{Hg} / \mathrm{HgCl}_{2}$ at $25{ }^{\circ} \mathrm{C}(0.242 \mathrm{~V})$.

\section{5. $\mathrm{CO}_{2}$ reduction measurements and products quantification}

The $\mathrm{CO}_{2}$ reduction measurements were performed in an airtight electrochemical H-type cell under ambient temperature. The cathode compartment was consist of working electrode and reference electrode, while the anode compartment was composed of platinum wire. Apply dots of $\mathrm{FeS}_{2} / \mathrm{NiS}$ nanocomposite catalyst (dissolved in $0.5 \%$ Nafion) to modified carbon fiber paper electrode $(0.7 \mathrm{~cm} \times 0.7 \mathrm{~cm})$, then connect the carbon fiber paper to the cathode electrode. Each of the compartments loaded $75.0 \mathrm{ml}$ 0.5 $\mathrm{M} \mathrm{KHCO}_{3}$ saturated with $\mathrm{CO}_{2}$ and $40.0 \mathrm{ml}$ carbon dioxide in the headspace. There is a slice of proton exchange membrane (Nafion ${ }^{\circledR} 212$ ) at the connector to separate the two compartments in case the electroreduction products diffused to the anode. The electrolytic measurements were carried out under different potentials for 1 hour, respectively. The durability test was measured in an open electrolytic cell with $0.5 \mathrm{M} \mathrm{KHCO}_{3}$ solution (saturated with $\mathrm{CO}_{2}$ ) for 4 hours at $-0.6 \mathrm{~V}$. During the measurement, carbon dioxide was bubbled into water continuously with a uniform velocity. The carbon-contained gas products $\left(\mathrm{CO}, \mathrm{CH}_{4}, \mathrm{C}_{2} \mathrm{H}_{4}\right.$, and $\left.\mathrm{C}_{2} \mathrm{H}_{6}\right)$ and major by-product $\left(\mathrm{H}_{2}\right)$ were tested by a thermal conductivity detector (TCD) with helium as the carrier gas. The liquid phase products were qualified by a NMR (Bruker AVANCEAV III 400) 
spectroscopy, in which $0.5 \mathrm{ml}$ electrolyte was mixed with $0.1 \mathrm{ml}$ $\mathrm{D}_{2} \mathrm{O}$ (deuterated water) and $0.05 \mu \mathrm{l}$ dimethyl sulfoxide (DMSO, Sigma, 99.99\%) was added as an internal standard.

The calculation of faradaic efficiency:

For $\mathrm{CH}_{3} \mathrm{OH}$,

$$
\mathrm{FE}_{\mathrm{CH}_{3} \mathrm{OH}}=\frac{6 F \times n_{\mathrm{CH}_{3} \mathrm{OH}}}{I \times t} \times 100 \%
$$

For $\mathrm{H}_{2}$,

$$
\mathrm{FE}_{\mathrm{H}_{2}}=\frac{2 F \times n_{\mathrm{H}_{2}}}{I \times t} \times 100 \%
$$

where $F$ is the Faraday constant, $n_{\mathrm{CH}_{3} \mathrm{OH}}$ is the moles of produced $\mathrm{CH}_{3} \mathrm{OH}$, and $n_{\mathrm{H}_{2}}$ for the produced $\mathrm{H}_{2}$.

\section{Results and discussion}

To explore the surface morphology of the $\mathrm{FeS}_{2} / \mathrm{NiS}$ nanocomposite, the SEM measurement was carried out as shown in Fig. 1a. The acquired products are made up of uniform and even nanoparticles with an average diameter of approximately $14 \mathrm{~nm}$. The small and even size of the electrocatalyst confirms high specific surface area and incremental active sites, which effectively improve the catalysis activity. The HRTEM image of $\mathrm{FeS}_{2} / \mathrm{NiS}$ nanocomposite is shown in Fig. 1b. The characteristic lattice spacing of $0.27 \mathrm{~nm}$ is corresponding to the (200) plane of $\mathrm{FeS}_{2}$ whose XRD peak is located at $2 \theta=33.0 .^{30}$ The lattice spacing of $0.29 \mathrm{~nm}$ is indexed to the (100) plane of the NiS which matches to the XRD peak at $2 \theta=46.0 .^{31}$ Fig. $1 \mathrm{c}$ shows the

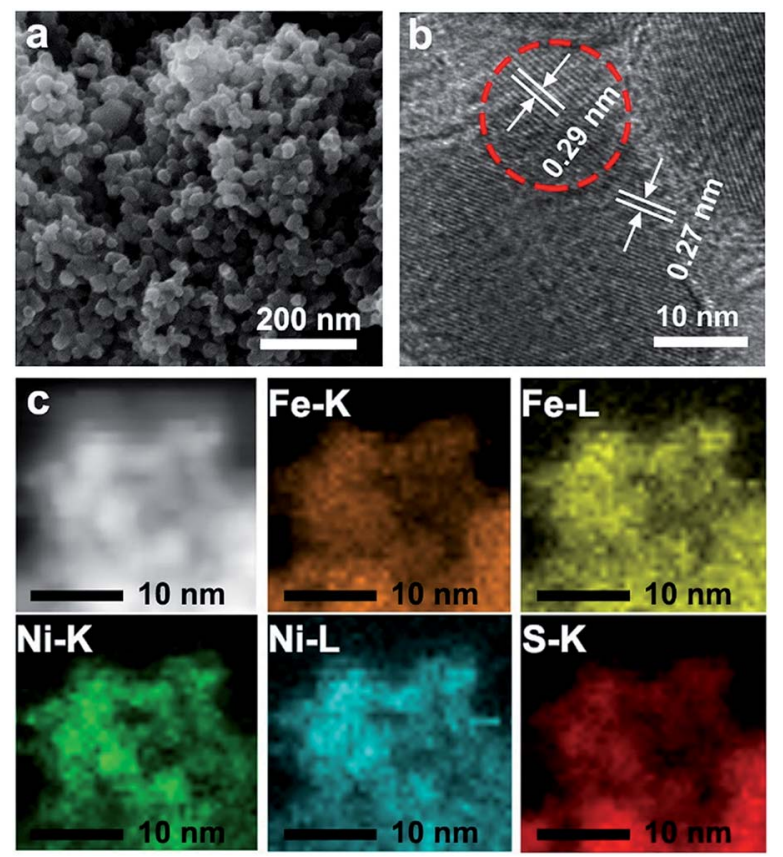

Fig. 1 (a) The SEM image of $\mathrm{FeS}_{2} / \mathrm{NiS}$ nanocomposite. (b) The HRTEM image of $\mathrm{FeS}_{2} / \mathrm{NiS}$ nanocomposite. (c) STEM image and corresponding chemical elements mappings of $\mathrm{Fe}-\mathrm{K}, \mathrm{Fe}-\mathrm{L}, \mathrm{Ni}-\mathrm{K}, \mathrm{Ni}-\mathrm{L}$ and $\mathrm{S}-\mathrm{K}$ of $\mathrm{FeS}_{2} / \mathrm{NiS}$ nanocomposite.
STEM image and corresponding chemical mappings of $\mathrm{Fe}-\mathrm{K}$, Fe-L, Ni-K, Ni-L and $\mathrm{S}-\mathrm{K}$ for $\mathrm{FeS}_{2} / \mathrm{NiS}$ nanocomposite. A homogeneous distribution of $\mathrm{Fe}, \mathrm{Ni}$, and $\mathrm{S}$ is reviewed in the nanocomposite. Furthermore, the HRTEM image concludes that the germination of $\mathrm{FeS}_{2} / \mathrm{NiS}$ nanocomposite arranges intimately rather than the simple physical mixture of the two compounds. Thus, we proposed that the active sites of $\mathrm{CO}_{2}$ electroreduction locate at the interface between $\mathrm{FeS}_{2}(200)$ and NiS (100).

In order to identify the crystallinity and structure of the $\mathrm{FeS}_{2} /$ NiS nanocomposite, the XRD measurements were performed. Fig. 2a shows the XRD patterns of $\mathrm{FeS}_{2} / \mathrm{NiS}$ nanocomposite (brown trace), $\mathrm{FeS}_{2}$ standard card (blue trace) and NiS standard card (red trace). The phanic peaks can be completely matched to the $\mathrm{FeS}_{2}$ (JCPDS no. 42-1340) and NiS (JCPDS no. 02-1280) standard diffraction peaks. In details, the predominant peaks at 46.0, 53.7, 30.2 and 34.7 degree correspond to the (100), (202), (101) and (102) planes of NiS, respectively. The peaks at 33.0, $56.4,37.1$ and 47.5 degree are assigned to the (200), (311), (210) and (211) planes of $\mathrm{FeS}_{2}$, respectively. There are no impurity peaks from other crystal structures. The average size of $\mathrm{FeS}_{2} / \mathrm{NiS}$ nanocomposite is $\sim 14 \mathrm{~nm}$ from the line width analysis of the diffraction peak calculated by Scherer equation, which is consistent with the SEM observation. $\mathrm{FeS}_{2} / \mathrm{NiS}$ nanocomposite was further characterized with Raman spectrum and showed in Fig. 2 b. The peaks at 340 and $378 \mathrm{~cm}^{-1}$ can be well attributed to Raman vibrations of pyrite $\mathrm{FeS}_{2}$ and no other impurity peaks from marcasite and troilite. ${ }^{30}$ The peaks at 222 and $285 \mathrm{~cm}^{-1}$ are matching with NiS completely. ${ }^{32}$ The peaks assigned to NiS at 335 and $376 \mathrm{~cm}^{-1}$ are not emerged in the diagram obviously, which is resulted by the overlap with the peaks of pyrite $\mathrm{FeS}_{2}$.

The XPS measurement was introduced to confirm the element proportion and valence state of the $\mathrm{FeS}_{2} / \mathrm{NiS}$ nanocomposite. Besides the Fe, $\mathrm{Ni}$ and $\mathrm{S}$ elements from $\mathrm{FeS}_{2} / \mathrm{NiS}$ nanocomposite, $\mathrm{C}$ and $\mathrm{O}$ elements are also detected in the full spectrum (as shown in Fig. 3a). The elements of $\mathrm{C}$ and $\mathrm{O}$ may attribute to the carbonization of the solvents. The high resolution spectra of $\mathrm{C} 1 \mathrm{~s}$ and $\mathrm{O} 1 \mathrm{~s}$ are shown in Fig. S1. $\uparrow$ The binding energy at 284.8, 286.4 and $288.8 \mathrm{eV}$ of $\mathrm{C} 1 \mathrm{~s}$ are consistent with graphite carbon, $\mathrm{C}-\mathrm{OH}$ and $\mathrm{C}=\mathrm{O}$, respectively. ${ }^{33}$ The $\mathrm{O}$ 1s peaks at 531.9 and $532.9 \mathrm{eV}$ from oxygen atoms are attributed to $\mathrm{C}=\mathrm{O}$ and $\mathrm{O}-\mathrm{C}$, respectively. ${ }^{34}$ The carbonized solvents with oxygenic functional groups may not only improve the stability of the
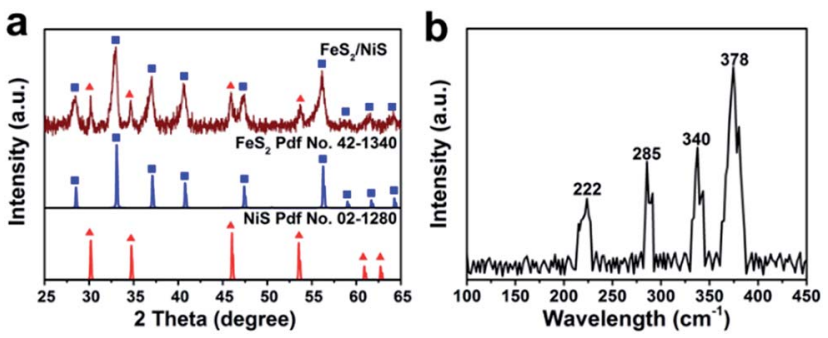

Fig. 2 (a) The large-angle XRD patterns of $\mathrm{FeS}_{2} / \mathrm{NiS}$ nanocomposite (brown trace), $\mathrm{FeS}_{2}$ (blue trace) and NiS (red trace). (b) Raman spectrum of $\mathrm{FeS}_{2} / \mathrm{NiS}$ nanocomposite. 

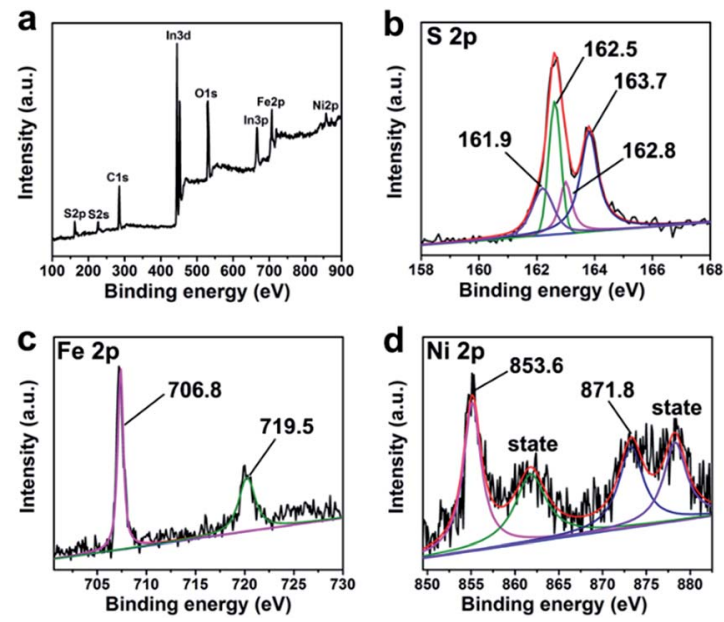

Fig. 3 (a) The full XPS spectrum of $\mathrm{FeS}_{2} / \mathrm{NiS}$ nanocomposite and the high-resolution XPS spectra of (b) S 2p, (c) Fe 2p and (d) Ni 2p.

catalyst but also act as a support. ${ }^{35}$ The high resolution scan spectra of the Fe 2p, Ni 2p and S 2p are presented in Fig. 3b-d. The atomic ratio of $\mathrm{Fe}$ to $\mathrm{Ni}$ is equal to 2 according to the XPS calculation. The result is consistent with the EDX spectroscopy measurement (as shown in Fig. S2 $\dagger$ ). The binding energy at 706.8 and $719.5 \mathrm{eV}$ are conformed to the $\mathrm{Fe} 2 \mathrm{p}^{3 / 2}$ and $\mathrm{Fe} 2 \mathrm{p}^{1 / 2}$ which are characterized of pyrite. ${ }^{36}$ The Ni $2 \mathrm{p}^{3 / 2}$ and Ni $2 \mathrm{p}^{1 / 2}$ peaks are observed at 853.6 and $871.8 \mathrm{eV}$, exist two satellite peaks at 858.7 and $878.1 \mathrm{eV}$ respectively, ${ }^{32}$ indicating that the nickel existed in bivalent states. There are four peaks in the high resolution XPS spectra of $S$. The $S 2 \mathrm{p}^{3 / 2}$ and $S 2 \mathrm{p}^{1 / 2}$ peaks located at 161.9 and $162.8 \mathrm{eV}$ are consistent with $\mathrm{S}^{2-},{ }^{31}$ while the peaks at 162.5 and $163.7 \mathrm{eV}$ are identified with the $S 2 \mathrm{p}^{3 / 2}$ and $\mathrm{S} 2 \mathrm{p}^{1 / 2}$ of $\mathrm{S}_{2}{ }^{2-} \cdot{ }^{37}$ These results indicate that both $\mathrm{S}_{2}{ }^{2-}$ and $\mathrm{S}^{2-}$ are existed. Thus, we integrate the peak areas respectively and acquire the ratio of $\mathrm{S}_{2}{ }^{2-}$ to $\mathrm{S}^{2-}$ is 2 , which is also consistent with the previously calculated ratio of iron to nickel.

In typical experiments, the electrolytic activities were measured in a three-electrode system in $0.5 \mathrm{M} \mathrm{KHCO}_{3}$ aqueous solution. The curves of Linear Sweep Voltammetry (LSV) for the $\mathrm{FeS}_{2} / \mathrm{NiS}$ nanocomposite are shown in Fig. 3a. The black curve shows the catalytic activity for HER under $\mathrm{N}_{2}$ atmosphere $(\mathrm{pH}=$ 8.5), which presents a high overpotential over $450 \mathrm{mV}$ and a low current density of $2.5 \mathrm{~mA} \mathrm{~cm} \mathrm{~cm}^{-2}$ with the applied potential up to $-0.68 \mathrm{~V}$. In comparison, an obvious enhancement of current density of $7.8 \mathrm{~mA} \mathrm{~cm}^{-2}$ is observed at the potential of $-0.68 \mathrm{~V}$ when the electrolyte is saturated with $\mathrm{CO}_{2}(\mathrm{pH}=7.5)$. The onset potential performs more positive at $-0.30 \mathrm{~V}$, indicating a low overpotential less than $280 \mathrm{mV}$ (confirmed by GC and ${ }^{1} \mathrm{H}$ NMR). The results reveal that the electrocatalyst can selectively reduce $\mathrm{CO}_{2}$ and suppress the HER efficiently under $\mathrm{CO}_{2}$ atmosphere.

As a comparison, we investigated the electrocatalytic performances of $\mathrm{FeS}_{2}$ nanocrystal and NiS nanocrystal for $\mathrm{CO}_{2}$ electroreduction, respectively. The detailed synthetic process is shown in Experiment section. The specific characterizations including XRD, SEM and TEM of the as-prepared $\mathrm{FeS}_{2}$ and NiS nanocrystals are shown in Fig. S3 and S4. $\uparrow$ The LSVs of $\mathrm{FeS}_{2}$, NiS and $\mathrm{FeS}_{2} / \mathrm{NiS}$ were measured in $\mathrm{CO}_{2}$-saturated $0.5 \mathrm{M} \mathrm{KHCO}_{3}$ solution. As showed in Fig. 4b, both the single $\mathrm{FeS}_{2}$ and NiS nanocrystals show poor activities towards $\mathrm{CO}_{2} \mathrm{RR}$ compared with $\mathrm{FeS}_{2} / \mathrm{NiS}$ nanocomposite, in which the $\mathrm{FeS}_{2}$ shows an onset potential at $-0.45 \mathrm{~V}$ for HER and the maximum current density of $4.2 \mathrm{~mA} \mathrm{~cm}^{-2}$ at $-0.68 \mathrm{~V}$. While the NiS nanocrystal performs even worse, which shows an extremely low current density of 1 $\mathrm{mA} \mathrm{cm}^{-2}$ at $-0.68 \mathrm{~V}$ (red trace). It is generally known that $\mathrm{FeS}_{2}$ is feasible towards HER. ${ }^{38,39}$ For $\mathrm{FeS}_{2} / \mathrm{NiS}$ nanocomposite (black trace), more positive onset potential at $-0.3 \mathrm{~V}$ as well as higher current density of $7.8 \mathrm{~mA} \mathrm{~cm}{ }^{-2}$ can be achieved towards $\mathrm{CO}_{2} \mathrm{RR}$.

To further compare the electrocatalytic performance of $\mathrm{FeS}_{2}$ nanocrystal, NiS nanocrystal and $\mathrm{FeS}_{2} / \mathrm{NiS}$ nanocomposite for $\mathrm{CO}_{2}$ reduction, the electrolytic reduction reaction of $\mathrm{CO}_{2}$ was carried out in an electrochemical airtight $\mathrm{H}$-type cell at the potential range from -0.3 to $-0.7 \mathrm{~V}$. The gas products were detected by gas chromatography (GC). The liquid-phase products were detected by ${ }^{1} \mathrm{H}$ NMR and the DMSO was added as an internal standard. As shown in Fig. $\mathrm{S} 5, \uparrow$ the reduced products are $\mathrm{CH}_{3} \mathrm{OH}$ after $\mathrm{CO}_{2}$ electroreduction catalyzed by $\mathrm{FeS}_{2} / \mathrm{NiS}$ nanocomposite for 2 hours and 4 fours. For $\mathrm{FeS}_{2}$ and NiS nanocrystals, $\mathrm{H}_{2}$ is the only product in gas phase and no hydrocarbon products are detected in both gas and liquid phases. As shown in Fig. 4c, the FEs $v s$. the applied potentials $(-0.5,-0.6,-0.7 \mathrm{~V})$ of $\mathrm{H}_{2}$ for $\mathrm{FeS}_{2}$ and NiS nanocrystals show a stable tendency at different potentials. For $\mathrm{FeS}_{2} / \mathrm{NiS}$ nanocomposite, the FEs $v s$. the applied potentials $(-0.3,-0.4,-0.5$, $-0.6,-0.7 \mathrm{~V}$ ) for $\mathrm{CH}_{3} \mathrm{OH}$ (left axis) and $\mathrm{H}_{2}$ (right axis) are shown in Fig. $4 \mathrm{~d}$. The $\mathrm{CH}_{3} \mathrm{OH}$ FEs show an overall growth tendency at the range from $-0.3 \mathrm{~V}$ to $-0.6 \mathrm{~V}$ but reach a plateau of $64 \%$ approximately at $-0.6 \mathrm{~V}$. After that, it maintains a stable tendency. We further compared the FEs for $\mathrm{CH}_{3} \mathrm{OH}$ in the literatures and showed in Table S1. $\dagger$ To reach the same FE of

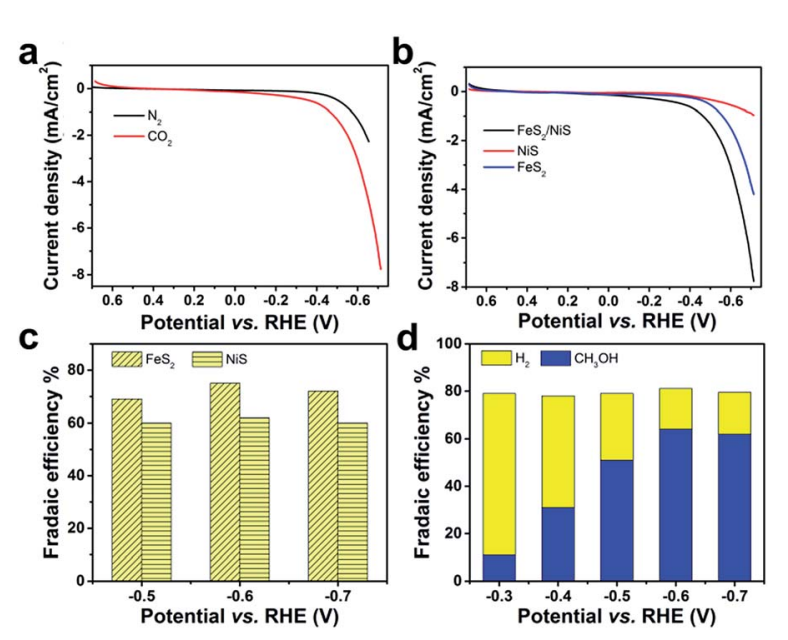

Fig. 4 (a) LSVs of $\mathrm{FeS}_{2} / \mathrm{NiS}$ nanocomposite in $0.5 \mathrm{M} \mathrm{KHCO}_{3}$ aqueous solution under $\mathrm{N}_{2}$ (blue trace) and $\mathrm{CO}_{2}$ (red trace) atmosphere; (b) LSVs of $\mathrm{FeS}_{2} / \mathrm{NiS}$ nanocomposite (black trace), NiS (red trace), and $\mathrm{FeS}_{2}$ (blue trace) in $0.5 \mathrm{M} \mathrm{KHCO}_{3}$ aqueous solution under $\mathrm{CO}_{2}$ atmosphere; (c) faradaic efficiencies vs. potential of $\mathrm{H}_{2}$ for $\mathrm{FeS}_{2}$ and NiS nanocrystals; (d) faradaic efficiencies vs. potential of $\mathrm{CH}_{3} \mathrm{OH}$ and $\mathrm{H}_{2}$ for $\mathrm{FeS}_{2} / \mathrm{NiS}$ nanocomposite. 
$\mathrm{CH}_{3} \mathrm{OH}, \mathrm{FeS}_{2} / \mathrm{NiS}$ nanocomposite shows a moderate potential compared with those noble metal electrocatalysts. The $\mathrm{H}_{2}$ FEs for $\mathrm{FeS}_{2} / \mathrm{NiS}$ nanocomposite show an opposite tendency compared with $\mathrm{CH}_{3} \mathrm{OH}$. The FEs of $\mathrm{H}_{2}$ continuously decreases and decreases to a minimum of $17 \%$ at the applied potential of $-0.6 \mathrm{~V}$. Moreover, the total FEs for the generation of $\mathrm{CH}_{3} \mathrm{OH}$ and $\mathrm{H}_{2}$ are maintained at $81 \%$ over the whole process. These results demonstrate that single $\mathrm{FeS}_{2}$ and NiS nanocrystals can hardly reduce $\mathrm{CO}_{2}$ into hydrocarbon products, whereas the $\mathrm{FeS}_{2} / \mathrm{NiS}$ nanocomposite can achieve an efficient and selective electroreduction process for $\mathrm{CO}_{2}$. Thus, we propose the active sites for $\mathrm{CO}_{2} \mathrm{RR}$ locate at the interface between $\mathrm{FeS}_{2}$ and NiS.

To further prove the stability of the $\mathrm{FeS}_{2} / \mathrm{NiS}$ nanocomposite, the continuous tendency test was measured in a standard threeelectrode cell as shown in Fig. 5a. A stable current density of 3.1 $\mathrm{mA} \mathrm{cm} \mathrm{cm}^{-2}$ is observed over the 4 hours electroreduction at the potential of $-0.6 \mathrm{~V}$. Besides, the FE of the products $\left(\mathrm{CH}_{3} \mathrm{OH}\right.$ and $\mathrm{H}_{2}$ ) for the $\mathrm{FeS}_{2}$ /NiS nanocomposite is maintained at about $81 \%$ over the 4 hours electrolysis. It can observe no obvious deactivation of $\mathrm{FeS}_{2} / \mathrm{NiS}$ nanocomposite for $\mathrm{CO}_{2}$ reduction throughout the entire process. Then, the XRD measurement was performed on the reacted $\mathrm{FeS}_{2} / \mathrm{NiS}$ nanocomposite as shown in Fig. $5 \mathrm{~b}$. The XRD analysis indicates that there is no transformation taking place upon the catalyst during the whole electroreduction. These results fully confirm that $\mathrm{FeS}_{2} / \mathrm{NiS}$ nanocomposite is excellently stable and efficient for $\mathrm{CO}_{2}$ electroreduction.

To understand the highly efficient electrocatalysis activity of $\mathrm{FeS}_{2} / \mathrm{NiS}$ nanocomposite, we further compared the performances of $\mathrm{CO}_{2} \mathrm{RR}$ catalysed by $\mathrm{FeS}_{2} / \mathrm{NiS}$ nanocomposite, pure $\mathrm{FeS}_{2}$ and NiS nanocrystals. The single $\mathrm{FeS}_{2}$ and NiS nanocrystals show poor activities towards $\mathrm{CO}_{2} \mathrm{RR}$. The $\mathrm{FeS}_{2}$ nanocrystal shows a negative onset potential at $-0.45 \mathrm{~V}$ and the maximum current density of $4.2 \mathrm{~mA} \mathrm{~cm}^{-2}$ at $-0.68 \mathrm{~V}$. Then, the NiS nanocrystal shows a more negative onset potential at $-0.5 \mathrm{~V}$ and extremely low current density of $1 \mathrm{~mA} \mathrm{~cm} \mathrm{~cm}^{-2}$ at $-0.68 \mathrm{~V}$. Furthermore, a physical mixture of $\mathrm{FeS}_{2}$ and NiS nanocrystals with the same ratio as $\mathrm{FeS}_{2} / \mathrm{NiS}$ nanocomposite was fabricated. The electrocatalytic activity for $\mathrm{CO}_{2}$ reduction was measured and showed in Fig. S6. $\dagger$ The current density presents a slight increasement under $\mathrm{CO}_{2}$ atmosphere compared with $\mathrm{N}_{2}$ atmosphere. Then, a 2 h-electrolysis in $0.5 \mathrm{M} \mathrm{CO}_{2}$-saturated $\mathrm{KHCO}_{3}$ for the physical
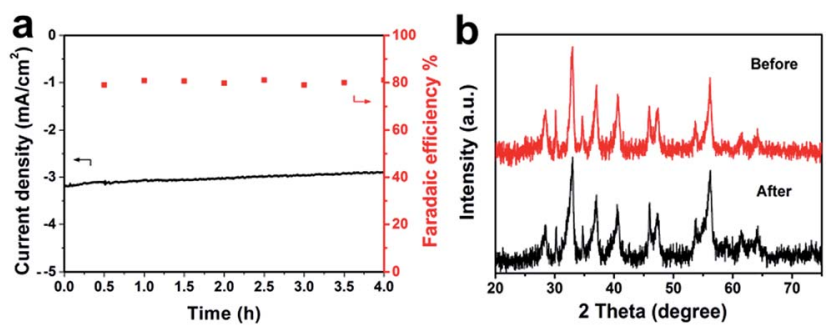

Fig. 5 (a) Stability of $\mathrm{FeS}_{2} / \mathrm{NiS}$ nanocomposite for $\mathrm{CO}_{2}$ reduction operated at a potential of -0.6 V vs. RHE for 4 hours. Geometric current density vs. time (left axis) and total $\mathrm{FE}$ for production $\left(\mathrm{CH}_{3} \mathrm{OH}\right.$ and $\mathrm{H}_{2}$ ) vs. time (right axis); (b) the large-angle XRD patterns of $\mathrm{FeS}_{2} /$ $\mathrm{NiS}$ nanocomposite before (red trace) and after (black trace) 4 hours electroreduction.

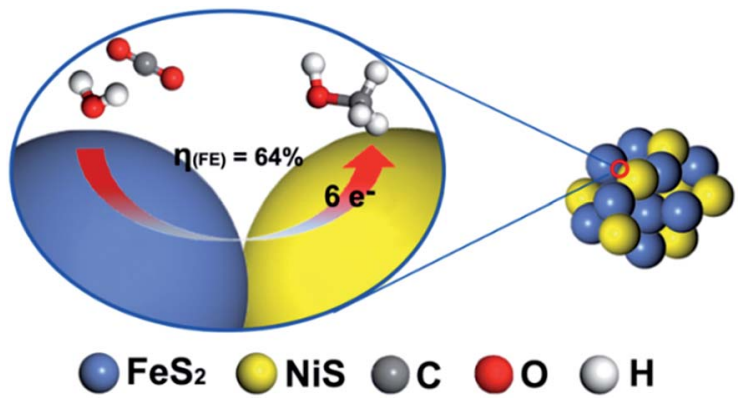

Fig. 6 The proposed reaction mechanism of electroreduction $\mathrm{CO}_{2}$ by $\mathrm{FeS}_{2} / \mathrm{NiS}$ nanocomposite electrocatalyst.

mixture was performed at the potential of $-0.6 \mathrm{~V}$. Only $\mathrm{H}_{2}$ was detected in the both gas phase and liquid phase products. The increasement of current density may be ascribed to the effect of pH. In contrast, the $\mathrm{FeS}_{2} / \mathrm{NiS}$ nanocomposite exhibits excellent activity for $\mathrm{CO}_{2} \mathrm{RR}$. It achieves an unprecedented overpotential of $280 \mathrm{mV}$ and a stable current density of $3.1 \mathrm{~mA} \mathrm{~cm}^{-2}$ at the potential of $-0.6 \mathrm{~V}$. Comparing the electrocatalytic performances of $\mathrm{CO}_{2} \mathrm{RR}$ in $\mathrm{FeS}_{2}$ nanocrystal, NiS nanocrystal, physical mixture of $\mathrm{FeS}_{2}$ and NiS nanocrystals and $\mathrm{FeS}_{2} / \mathrm{NiS}$ nanocomposite, it can speculate that the active sites of the catalyst locate at the interface between $\mathrm{FeS}_{2}$ (200) and NiS (100) (as shown in Fig. 6). On the other hand, many researches have evidenced that the electroreduction of $\mathrm{CO}_{2}$ to $\mathrm{CH}_{3} \mathrm{OH}$ is a complex process which includes the transformation of $6 \mathrm{e}^{-}$and $6 \mathrm{H}^{+} .^{5,37-40}$ Still, more experimental and theoretical calculations are needed to unravel the detailed mechanism of this multistep reaction.

\section{Conclusion}

We synthesized the $\mathrm{FeS}_{2} / \mathrm{NiS}$ nanocomposite with a traditional hydrothermal method. It was demonstrated that $\mathrm{FeS}_{2} / \mathrm{NiS}$ nanocomposite can catalyze $\mathrm{CO}_{2} \mathrm{RR}$ at an unprecedented overpotential of $280 \mathrm{mV}$ and a high $\mathrm{CH}_{3} \mathrm{OH}$ faradaic efficiency up to $64 \%$ at the potential of $-0.6 \mathrm{~V}$. Moreover, the catalyst performs a stable current density of $3.1 \mathrm{~mA} \mathrm{~cm}^{-2}$ over the 4 hours stability test and there is no obvious degradation after electroreduction from XRD observation. In experiments, the $\mathrm{FeS}_{2}$ nanocrystals, NiS nanocrystals and the physical mixture of $\mathrm{FeS}_{2}$ and NiS nanocrystals all show poor activity towards $\mathrm{CO}_{2} \mathrm{RR}$, while the $\mathrm{FeS}_{2} / \mathrm{NiS}$ nanocomposite exhibits excellent activity towards the process. Thus, the high activity and selectivity towards $\mathrm{CO}_{2}$ electroreduction to $\mathrm{CH}_{3} \mathrm{OH}$ is probably attributed to the special ladder structure of the $\mathrm{FeS}_{2} / \mathrm{NiS}$ nanocomposite. The active sites may locate at the interface between $\mathrm{FeS}_{2}$ and NiS which could effectively suppress the side reaction of HER and facilitate the $\mathrm{CO}_{2} \mathrm{RR}$. The low-cost $\mathrm{FeS}_{2} / \mathrm{NiS}$ nanocomposite is an efficient alternative to expensive materials for the application of $\mathrm{CO}_{2}$ electroreduction in industry.

\section{Acknowledgements}

This work is supported by the Collaborative Innovation Center of Suzhou Nano Science and Technology, the National Natural 
Science Foundation of China (51422207, 51132006, 51572179, 21471106, 21501126), the Specialized Research Fund for the Doctoral Program of Higher Education (20123201110018), a Suzhou Planning Project of Science and Technology (ZXG2012028), and a project funded by the Priority Academic Program Development of Jiangsu Higher Education Institutions (PAPD).

\section{Notes and references}

1 Q. Lu, J. Rosen, Y. Zhou, G. S. Hutchings, Y. C. Kimmel, J. G. Chen and F. Jiao, Nat. Commun., 2014, 5, 3242.

2 R. Reske, H. Mistry, F. Behafarid, B. Roldan Cuenya and P. Strasser, J. Am. Chem. Soc., 2014, 136, 6978-6986.

3 J. Wu, R. M. Yadav, M. Liu, P. P. Sharma, C. S. Tiwary, L. Ma, X. Zou, X.-D. Zhou, B. I. Yakobson, J. Lou and P. M. Ajayan, ACS Nano, 2015, 9, 5364-5371.

4 J. O. Bockris, J. Electrochem. Soc., 1989, 136, 2521.

5 J. Qiao, Y. Liu, F. Hong and J. Zhang, Chem. Soc. Rev., 2014, 43, 631-675.

6 W. Zhu, R. Michalsky, Ö. Metin, H. Lv, S. Guo, C. J. Wright, X. Sun, A. A. Peterson and S. Sun, J. Am. Chem. Soc., 2013, 135, 16833-16836.

7 S. Back, M. S. Yeom and Y. Jung, ACS Catal., 2015, 5, 50895096.

8 H. Mistry, R. Reske, Z. Zeng, Z.-J. Zhao, J. Greeley, P. Strasser and B. R. Cuenya, J. Am. Chem. Soc., 2014, 136, 16473-16476. 9 W. Zhu, Y.-J. Zhang, H. Zhang, H. Lv, Q. Li, R. Michalsky, A. A. Peterson and S. Sun, J. Am. Chem. Soc., 2014, 136, 16132-16135.

10 J. Rosen, G. S. Hutchings, Q. Lu, S. Rivera, Y. Zhou, D. G. Vlachos and F. Jiao, ACS Catal., 2015, 5, 4293-4299.

11 S. Ma, R. Luo, J. I. Gold, A. Z. Yu, B. Kim and P. J. A. Kenis, J. Mater. Chem. A, 2016, 4, 8573-8578.

12 D. Gao, H. Zhou, J. Wang, S. Miao, F. Yang, G. Wang, J. Wang and X. Bao, J. Am. Chem. Soc., 2015, 137, 4288-4291.

13 X. Wang, H. Shi, J. H. Kwak and J. Szanyi, ACS Catal., 2015, 5, 6337-6349.

14 Y. Gong, Y. Zhao, Y. Chen, Y. Wang and C. Sun, RSC Adv., 2016, 6, 43185-43190.

15 J. Albo, M. Alvarez-Guerra, P. Castaño and A. Irabien, Green Chem., 2015, 17, 2304-2324.

16 C. Zhai, M. Zhu, F. Pang, D. Bin, C. Lu, M. C. Goh, P. Yang and Y. Du, ACS Appl. Mater. Interfaces, 2016, 8, 5972-5980.

17 C. Zhai, M. Zhu, D. Bin, F. Ren, C. Wang, P. Yang and Y. Du, J. Power Sources, 2015, 275, 483-488.

18 D. Canfield and K. W. Frese, J. Electrochem. Soc., 1983, 130, 1772.
19 K. W. Frese and S. Leach, J. Electrochem. Soc., 1985, 132, 259260.

20 K. Hara, A. Kudo and T. Sakata, J. Electroanal. Chem., 1995, 386, 257-260.

21 A. Kudo, S. Nakagawa, A. Tsuneto and T. Sakata, J. Electrochem. Soc., 1993, 140, 1541-1545.

22 K. Hara, A. Tsuneto, A. Kudo and T. Sakata, J. Electrochem. Soc., 1994, 141, 2097-2103.

23 S. Bagherzadeh and N. P. Mankad, J. Am. Chem. Soc., 2015, 137, 10898-10901.

24 G. Kyriacou and A. Anagnostopoulos, J. Electroanal. Chem., 1992, 322, 233-246.

25 J. B. Varley, H. A. Hansen, N. L. Ammitzbøll, L. C. Grabow, A. A. Peterson, J. Rossmeisl and J. K. Nørskov, ACS Catal., 2013, 3, 2640-2643.

26 A. B. Bocarsly, Q. D. Gibson, A. J. Morris, R. P. L'Esperance, Z. M. Detweiler, P. S. Lakkaraju, E. L. Zeitler and T. W. Shaw, ACS Catal., 2012, 2, 1684-1692.

27 H. Mistry, A. S. Varela, C. S. Bonifacio, I. Zegkinoglou, I. Sinev, Y.-W. Choi, K. Kisslinger, E. A. Stach, J. C. Yang, P. Strasser and B. R. Cuenya, Nat. Commun., 2016, 7, 12123.

28 D. Raciti, K. J. Livi and C. Wang, Nano Lett., 2015, 15, 68296835.

29 M. Le, M. Ren, Z. Zhang, P. T. Sprunger, R. L. Kurtz and J. C. Flake, J. Electrochem. Soc., 2011, 158, E45.

30 B.-B. Yu, X. Zhang, Y. Jiang, J. Liu, L. Gu, J.-S. Hu and L.-J. Wan, J. Am. Chem. Soc., 2015, 137, 2211-2214.

31 J. Yuan, J. Wen, Y. Zhong, X. Li, Y. Fang, S. Zhang and W. Liu, J. Mater. Chem. A, 2015, 3, 18244-18255.

32 J. S. Chen, J. Ren, M. Shalom, T. Fellinger and M. Antonietti, ACS Appl. Mater. Interfaces, 2016, 8, 5509-5516.

33 L. Bai, S. Qiao, Y. Fang, J. Tian, J. Mcleod, Y. Song, H. Huang, Y. Liu and Z. Kang, J. Mater. Chem. C, 2016, 4, 8490-8495.

34 B. Y. Yu and S.-Y. Kwak, J. Mater. Chem., 2012, 22, 8345.

35 H. Li, X. Zhang and D. R. MacFarlane, Adv. Energy Mater., 2015, 5, 1401077.

36 F. Jiang, L. T. Peckler and A. J. Muscat, Cryst. Growth Des., 2015, 15, 3565-3572.

37 R. Morrish, R. Silverstein and C. A. Wolden, J. Am. Chem. Soc., 2012, 134, 17854-17857.

38 D.-Y. Wang, M. Gong, H.-L. Chou, C.-J. Pan, H.-A. Chen, Y. Wu, M.-C. Lin, M. Guan, J. Yang, C.-W. Chen, Y.-L. Wang, B.-J. Hwang, C.-C. Chen and H. Dai, J. Am. Chem. Soc., 2015, 137, 1587-1592.

39 D. Jasion, J. M. Barforoush, Q. Qiao, Y. Zhu, S. Ren and K. C. Leonard, ACS Catal., 2015, 5, 6653-6657.

40 A. Roldan and N. H. de Leeuw, Faraday Discuss., 2016, 188, 161-180. 